Makale türü: Araştırma

\title{
Sosyal Hizmet Bölümü Öğrencilerinin Geleceğe Yönelik Mesleki ve Akademik Beklentileri \\ $* * *$
}

\section{Professional and Academic Expectation for the Future of Students of Social Work}

\author{
Arş. Gör. Kaan SEVİM \\ İstanbul Sabahattin Zaim Üniversitesi, Sosyal Hizmet Bölümü, \\ kaan.sevim@izu.edu.tr \\ Arş. Gör. Fatih ALTUN \\ İstanbul Sabahattin Zaim Üniversitesi, Sosyal Hizmet Bölümü, \\ fatih.altun@izu.edu.tr
}

\section{Özet}

Sosyal Hizmet bölümü Türkiye'de son 5 yıl içerisinde hem devlet üniversitelerinde hem de vakıf üniversitelerinde hızlı bir artış göstermiştir. Bu hızlı artışın getirmiş olduğu problemlerin öğrenciler üzerinde nasıl bir etki yarattığı ve kendilerini gelecek beklentileri üzerinden akademik ve mesleki bağlamda nasıl yorumladıkları önemli bir konu haline gelmektedir. Artan niceliğin öğrenci odağında nasıl tepki gördüğü ve nitelik bakımından nasıl algılandığı soruları da ayrıca bu çalışmanın üzerinde durmak istediği noktalar olmuştur. Aynı zamanda bu çalışmada Sosyal Hizmet bölümü öğrencilerinin akademik ve mesleki beklentilerinin betimlemeye çalışarak hızla artan bölüm sayısının, öğrenci merkezli bir yaklaşımla, nasıl karşılık bulduğu araştırılmaya çalışılacaktır.

Anahtar Kelime: Akademik Beklenti, Mesleki Beklenti, Sosyal Hizmet.

\begin{abstract}
The Social Work Major has shown a rapid increase in Turkey over the past 5 years in both public and private universities. It is becoming an important issue how the problems brought about by this rapid increase have had an impact on students and how they have interpreted by students in the academic and professional context through their expectation for the future. Increasing the number of Social Work Major in universities how students react and how it is perceived in terms of quality has been a point that this study would like to emphasize. At the same time, in this study, it will be tried to investigate both how the rapidly increasing number of SW Majors are perceived by students and tried to describe the academic and professional expectations of the students especially with a student-centered approach.
\end{abstract}

Keywords: Academic Expectancy, Professional Expectancy, Social Work.

\section{GİRIȘ}

Makale gönderim tarihi / Received: 27.10.2017, Kabul tarihi / Accepted: 14.11.2017 
İnsanlık var olduğundan beri hümanist ya da dini duygularla toplumdaki ihtiyaç sahiplerine yönelik çeşitli yardım ve hizmet uygulamaları geliştirilmiştir (Pierson, 2012: 11). Sanayi devrimi sonrasında yaşanan hızlı kentleşme beraberinde birçok sorunu getirmiştir. Kentlerde oluşan yoksul bölgelerde hem bireylere hem de ailelere yönelik gönüllü çalışmalar sürdürülmeye başlanmıştır. Bu gelişmeler modern anlamda sosyal hizmet mesleğinin doğuşunu hızlandırmıştır. Yürütülen çalışmalar ülkelerin sosyoekonomik, siyasi ve kültürel şartlarına göre şekillenmiştir. Süreç içerisinde gönüllü çalışmalar profesyonel bir zemine oturtulmuş olup bilimsel nitelik kazanmıştır. (Acar ve Çamur Duyan, 2003: 18).

Sosyal hizmet, bireylerin ve toplumların sosyal gelişimlerini desteklemeye ve çıkabilecek sorunlara karşı daha etkili bir çözüm önerisi getirebilecek bir meslek dalıdır (Öztürk, 2009: 105). Sosyal hizmet hem akademik açıdan hem de uygulama alanları açısından da iyi bir eğitimden geçmiş ve ortak bir mesleki etiğe sahip sosyal hizmet uzmanları tarafından gerçekleştirilmektedir (Freund, 2006: 67). Sosyal hizmet mesleğinin en önemli amacı ezilen, incinebilir konumda olan ve yoksulluk içinde yaşayan kişileri güçlendirmek ve onların refahını artırmaktır (Gökçearslan Çiftçi ve Gönen, 2011: 149). Sosyal hizmet insanların daha özgür ve daha güçlü olmas1 için çaba harcamaktadır. Bu çabaları eğitim, araştırma ve uygulama ile bütünleştirerek topluma katkı sağlamayı hedeflemektedir. Bu bağlamda, sosyal hizmet alanında hem lisans hem de lisansüstü düzeyde eğitim programları yürütülmekte, müracaatçılara yönelik uygulamalar sürdürülmektedir. Sosyal hizmet araştırma boyutunda ise hem uygulama alanında karşılaşılan problemlere yönelik yeni politikalar üretme hem de ürettiği politikalarla sunulan hizmetlerin kalitesini arttırmayı amaçlayan bir yapıya sahiptir. $\mathrm{Bu}$ da sosyal hizmet eğitiminin önemini ön plana çıkarmaktadır (Işıkhan, Erbay, Akçay ve Ege, 2016: 8). Sosyal hizmet mesleği ortaya çıktığı günden günümüze toplumun sosyal refah ve iyilik halini ilgilendiren sosyal politikaların oluşturulmasına katkıda bulunmuştur (Danış, 2007: 52). Sosyal çalışmacıların mesleğe ilişkin algıları, müracaatçılarına yararlı ve profesyonel yardım hizmetleri sağlamaları açısından öenmli bir etkiye sahiptir (Freund, 2006: 67). Sosyal hizmet mesleğinin amac1 yoksul 
kişilere yardım etmek olması, bu mesleği seçmede en büyük etken oluşturduğu düşünülebilir fakat bu yardım etmenin yanı sıra, sosyal hizmet alanında kariyer edinme kendi sosyal ve kişisel gelişimi ile ilgili değerler ve meslekte ilerleme, mesleki statü kazanma gibi meslek tercihini etkileyen çok fazla belirleyicilerin olduğu görülmektedir (Wilson ve McCrystal, 2007: 36).

Sosyal hizmet göreceli olarak hala genç bir meslektir. Bundan dolayı, son derece kararlı ve profesyonel bireylerin bu mesleğe ilgilerini çekebilmek açısından bireylerin sosyal hizmet algıları önem taşımaktadır (Olin, 2013: 93). Sosyal hizmet mesleği, insanların sorunlar ile başa çıkma kapasitelerini geliştirme, insanlar ile onlara hizmet veren kuruluşları buluşturma ve sosyal sistemlerin daha etkin ve insan onuruna yakışır şekilde çalışmasına katkıda bulunmak ve sosyal politikaların geliştirilmesine katkıda bulunmak gibi hedeflere sahiptir (Pincus ve Minahan, 1973: 9).

Dünyada bir asırdır devam eden sosyal hizmet disiplini ve mesleği Türkiye'de yaklaşık 50 yıldır devam etmektedir. İlk olarak 1961 yılında "Sosyal Hizmetler Akademisi" nin açılması ile Türkiye'de sosyal hizmet eğitimi başlatılmıştır. 1967 yılında Hacettepe Üniversitesi'ne bağlı olarak kurulan "Sosyal Çalışma ve Sosyal Hizmetler Bölümü” ile bölüm sayısı ikiye çıkmıştır. 1983 yılında kabul edilen 2547 Sayılı Yüksek Öğretim Kurulu (YÖK) Kanunu sonrasında bu iki bölüm “Sosyal Hizmetler Yüksekokulu” adı altında birleştirilmiştir. 1983 yılından 2003 yılına kadar Hacettepe Üniversitesine bağlı bu bölüm tek bölüm olarak varlığını sürdürmüştür. 2000'li yıllara gelindiğinde birlikte Türkiye'de yeni sosyal hizmet bölümlerinin açılmasını sağlayacak siyasi, sosyal, ekonomik ve kültürel bir zemin oluşmuştur (Alptekin, Topuz, ve Zengin, 2014: 353-354). Bu bağlamda, 2011 yılına kadar Türkiye'de sosyal hizmet bölüm sayıs1 10'u geçmezken, bu sayı 2014 yılında 36, 2016 yılında ise 41'e ulaşmıştır. (Yiğit, 2017: 157). 2011 y1lından sonra üniversitelerde açllan sosyal hizmet bölümü sayısı hızla artmaya başlamıştır. Buna bağlı olarak öğrenci kontenjanları da hızla yükselmiştir. Sosyal hizmet mesleğinin geniş bir çalışma bir alanına sahip olasına rağmen mezun sayısının yeterli düzeyde olmaması bu ihtiyaca yönelik gerekçelerin başında gelmektedir. Diğer bir açıdan ele alındığında 
büyümenin plansız bir şekilde gerçekleşmesi ve açılan bölümlerde bu eğitimi verecek sosyal hizmet eğitimi almış akademisyen sayısının yeterli miktarda olmaması önemli dezavantajlar oluşturmaktadır (Iş̧ıhan, Erbay, Akçay ve Ege, 2016: 9-10). Türkiye'de mevcut sosyal hizmet bölümlerinde görev yapan öğretim üyeleri incelendiğinde Sosyal Hizmet Lisans veya Lisansüstü eğitimi alanlar \%36, almayanlar ise \%64'lük bir orana sahiptir. Sosyal hizmetin disiplinlerarası niteliği gereği farklı alanlardan öğretim üyelerinin eğitim kadrosunda görev alması normal görülebilmektedir, Avrupa ve Kuzey Amerika'daki örneklerinde de farklı disiplinlerden öğretim üyelerinin bölüm kadrosunda yer aldığı bilinmektedir. Ancak Türkiye'deki oran söz konusu ülkelerin tam tersine bir hal almış alandaki öğretim üyesi yetersizliğinden dolayı ağırlıklı olarak farklı alanlardan öğretim üyeleri görev yapmaya başlamıştır. (Alptekin, Topuz ve Zengin, 2014: 361) Bununla birlikte sosyal hizmet alanındaki istihdam imkânları daralma sürecine girmiştir ve alanın sosyal çalışmacı ihtiyacının çok üzerinde mezun verilmeye başlanmıştır (Alptekin, Topuz ve Zengin, 2014: 364).

2011 yılında açı öğretimin de açılması ile birlikte, daha önceleri bahsedilen sosyal hizmet uzmanı ihtiyacı kavramı, plansız büyümenin sonucunda ilerleyen yıllarda istihdam sıkıntısı üzerine yoğunlaşacağı görünmektedir. Toplumların yaşamış olduğu sorunlar teknoloji ve birçok etki ile birlikte hızla farklılaşıp artarken bir yandan da profesyonel sosyal hizmete olan ihtiyacı artırmaktadır. Bu bağlamda hem sosyal hizmet akademisi hem de mesleği olarak nitelikli bir eğitim ve araştırma süreçlerinden geçmiş donanımlı meslek elemanları yetiştirebilmek bir hedef haline gelmiştir. $\mathrm{Bu}$ hedefin gerçekleşmesinde sosyal hizmet eğitimine ve akademisine önemli roller düşmektedir. $\mathrm{Bu}$ açıdan sosyal hizmet bölümde okumakta olan öğrencilerin neler düşündüğü, neler beklediği, geleceklerinin nasıl kurguladıkları ve var olan durumu nasıl değerlendirdiklerinin anlaşılması önem taşımaktadır.

\section{YÖNTEM}

Bu araştırmada, 2016-2017 öğretim yılında İstanbul Zaim Üniversitesi, Sosyal Hizmet Lisans Programı'na kayıtlı öğrencilerin tutumlarını incelendiğ için araştırma, tarama modeline dayalı olarak yürütülmüştür. Tarama 
modeline dayalı çalışmalar var olan bir durumu, var olduğu şekliyle açıklamaya çalışır (Karasar, 1999). Bu sayede varlıkların ya da nesnelerin özellikleri araştırılır ve ilişkileri ortaya konulur (Hovardaoğlu, 2000). Bu araştırmada da Sosyal Hizmet Lisans Programı'na kayıtlı öğrencilerin akademik ve mesleki geleceklerine yönelik tutumları mevcut koşullar altında var olduğu şekliyle ortaya konulmaktadır. Öğrencilerin tutumları herhangi bir etkileme ya da değiştirme çabasına gidilmeden olduğu gibi betimlemeyi amaçlamıştır.

Araştırma, kümelere göre örnekleme yöntemiyle yürütülmüş, veriler 2017 yılı Ocak ayında toplanmıştır. Veri toplama aracı olarak araştırmacılar tarafından sosyal hizmet öğrencilerinin sosyo-demografik özelliklerinin yanı sıra hem akademik hem de mesleki gelecek beklentilerini içiren toplamda 39 sorudan oluşan anket hazırlanmıştır. Oluşturulan anket aracılığıyla İstanbul Sabahattin Zaim Üniversitesinde birinci, ikinci, üçüncü ve dördüncü sınıfta okuyan öğrencilerden gönüllü olarak veriler toplanmıştır. Bu kapsamda; 1. sınıftan 56 kişi, 2. sınıftan 62 kişi, 3. sınıftan 31 kişi ve 4. sınıftan 20 kişi olmak üzere toplamda 169 öğrenci araştırmaya katılmıştır. Bölümdeki toplam öğrenci sayısı ise 243’tür. Elde edilen veriler IBM SPSS Statistic 23 paket programıla analiz edilmiştir.

\subsection{Problem}

Son dönemlerde sosyal hizmet örgün ve uzaktan eğitimlerinin hizla artmaya başlaması ile birlikte sosyal hizmet öğrencilerinin hem akademik hem de mesleki geleceklerinde nasıl etkiler oluşturabileceği tespit edilmeye çalışılacaktır. Literatür incelendiğinde sosyal hizmet öğrencilerinin gelecek beklentilerini odağına alan çalışmaların oldukça sınırlı olduğu görülmüştür. Öğrencilerin gelecek beklentilerini ortaya koyarak birçok araştırmada eksik kalan boşluğu doldurması planlanmaktadır. Ayrıca bu araştırma ile sosyal hizmet öğrencilerinin akademik ve mesleki gelecek planlarını ortaya koymak ve bu konudaki görüşlerini tespit etmek araştırmanın problemini oluşturmaktadır. 


\subsection{Amaç}

$\mathrm{Bu}$ araştırma, İstanbul Sabahattin Zaim Üniversitesi Sosyal Hizmet bölümünde eğitim gören 1. sınıf, 2. sınıf, 3. sınıf ve 4. sınıf öğrencilerinin akademik ve mesleki kaygılarını çok boyutlu olarak incelemeyi amaçlamaktadır. Araştırmanın alt amaçları ise soru cümleleri ile ifade edilmiştir.

- Sosyal hizmet öğrencilerinin sosyal hizmet mesleğine ve disiplinine yönelik değerlendirmeleri nelerdir?

- Sosyal hizmet öğrencileri mezun olduktan sonra hangi alanda çalışmayı düşünmektedir?

- Mesleki ve akademik anlamda yeterli ders kaynağına ulaşabilmekte midir?

- Mesleğin geleceğine yönelik kaygıları ne düzeydedir?

\section{BULGULAR VE YORUMLAR}

Sosyal hizmet bölümü öğrencilerinin demografik özelliklerine ilişkin bilgiler Tablo 1'de verilmiştir.

Tablo 1: Öğrencilere ilişkin sosyo-demografik bilgiler

\begin{tabular}{cccc}
\hline & & Sayı & $\%$ \\
\hline \multirow{2}{*}{ Cinsiyet } & Kadın & 130 & 77.4 \\
& Erkek & 39 & 22.6 \\
& Toplam & 169 & 100.0 \\
\hline \multirow{2}{*}{ Sınıf } & 1 & 56 & 33.3 \\
& 2 & 62 & 36.7 \\
& 3 & 31 & 18.5 \\
& 4 & 20 & 11.3 \\
Gönüllü çalışma durumu & Toplam & 169 & 100.0 \\
& Evet & 69 & 40.1 \\
& Hayır & 100 & 59.9 \\
& Toplam & 169 & 100.0 \\
\hline & 1-5 Arası & 110 & 65.9 \\
& 6-10 Arası & 31 & 17.4
\end{tabular}


Bölümü tercih sıranız

11-15 Arası

17

10.2

16-20 Aras1

8

4.8

21-25 Aras1

3

1.8

Toplam

169

100.0

Tablo 1'de görüldügü gibi araştırmaya katılan öğrencilerin cinsiyete göre dağılımına bakıldığında \%22.6'i erkek \%77.4's1 ise kadındır. Katılımc1ların \%33.3'ü 1. sınıf, \%36.7'si 2. sinıf, \%18.5'ü 3. sinıf ve \%11.3'ü son sınıf öğrencilerinden oluşmaktadır. Öğrencilere daha önce gönüllü olarak herhangi bir yerde çalışıp çalışmadıkları sorulmuş ve \%40.1'i daha önce gönüllü olarak çalışmış ve \%59.9'u gönüllü olarak çalışmadığını beyan etmiştir. Katılımcıların sosyal hizmet bölümünü tercih etme sıralamaları 1-5 aras1 \%65.9, 6-10 aras1 \%17.4, 11-15 aras1 \%10.2, 16-20 aras1 \% 4.8 ve 21-25 aras1 $\% 1.8$ olarak bulunmuştur.

Grafik 1: Öğrencilerin literatürü takip ettiği kaynaklar.

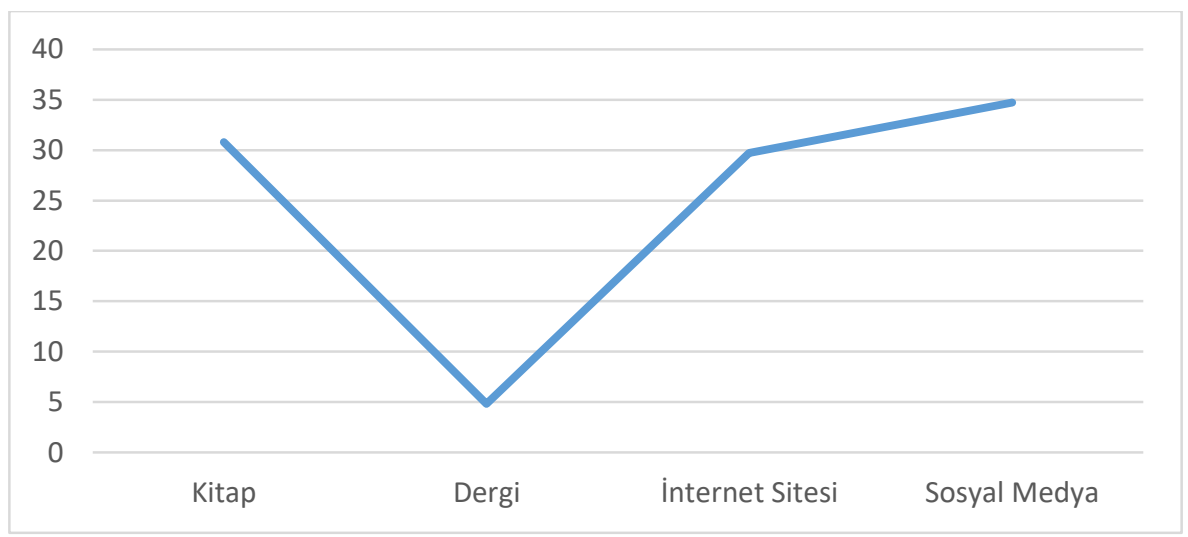

Sosyal hizmet bölümü Türkiye'de yaklaşık 50 yıldır varlığını sürdürmesine rağmen literatür olarak henüz tam olarak yeterli olduğu söylenememektedir. Öğrencilere bu konuda bir soru yöneltilerek literatürü hangi kaynaklardan takip ettikleri sorulmuştur. Grafik 1'de görüldüğü gibi, literatürü kitaptan takip edenler \%30.8, dergiden takip edenler $\% 4.8$, internet sitesinden takip edenler \%29.7 ve sosyal medyadan takip edenler ise \%34.7 
olarak bulunmuştur. Görüldüğü üzere sosyal hizmet literatürü en fazla sosyal medya ikinci olarak ise kitap üzerinden takip edildiği görülmüştür.

Grafik 2: Öğrencilerin çalışmayı düşündükleri alanlar.

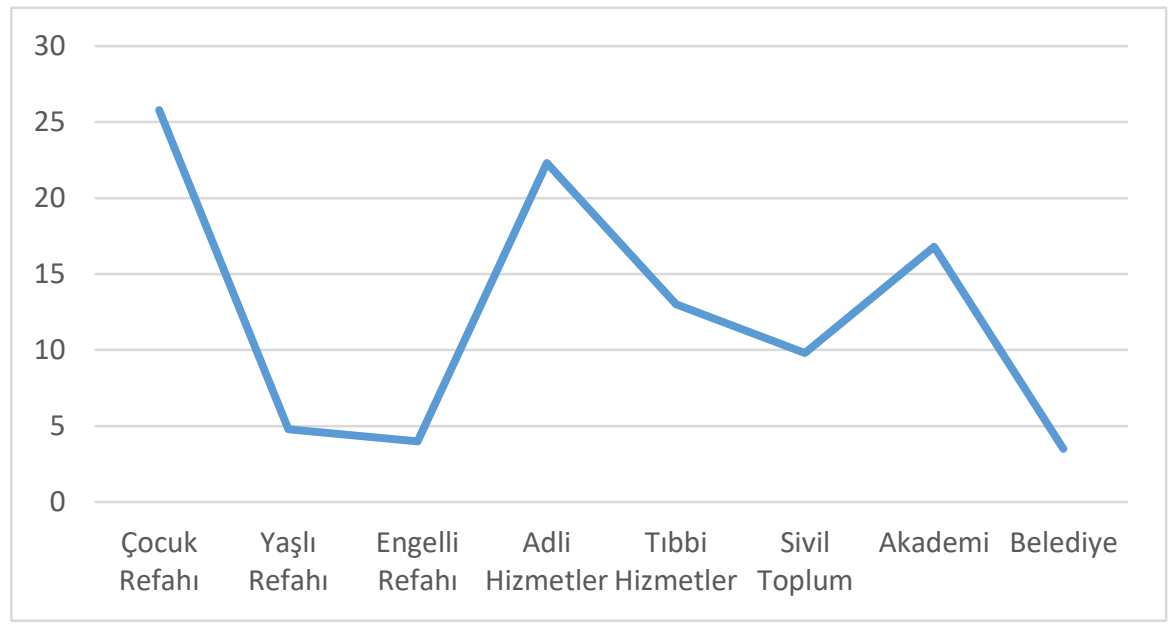

1952 yılında ABD'de sosyal hizmet eğitiminin niteliğini artırmak için kurulan Sosyal Hizmet Eğitimi Konseyi (The Council of Social Work Education) bölümün akreditasyonunun sağlanması olarak her sosyal hizmet eğitiminin genelci yaklaşıma göre sürdürülmesini şart koşmuştur. ${ }^{1}$ Genelci sosyal hizmet yaklaşımının amacı, sosyal çalışmacının farklı müracaatçı ve vakalara değişik kuram ve tekniklerin farklı düzlemlerde uygulanmasıdır (Sheafor ve Horejsi, 1989: 87).

Türkiye'de verilen sosyal hizmet eğitimi genelci yaklaşımın gereği olarak birey, aile, grup ve topluma yönelik tüm alanları kapsayacak bir şekilde verilmektedir. $\mathrm{Bu}$ yaklaşım gereği öğrenciler direk olarak bir alanda uzmanlaşmamaktadırlar. Ancak mezun olduktan sonra çalışacakları alanlar farklılaşmaktadır.

Bu bağlamda Grafik 2'de öğrencilerin mezun olduktan sonra hangi alanda çalışmayı düşündükleri sorulmuştur. Öğrencilerden gelen cevaplar doğrultusunda; çocuk alanında çalışmak isteyenlerin oranı \%25.8 ile birinci sırada çıkmıştır. Diğer alanlar ise sırası ile şu şekildedir; adli hizmetler \%22.3,

\footnotetext{
${ }^{1}$ http://www.socialworkdegreeguide.com/what-does-it-mean-to-be-a-social-workgeneralist (Erişim tarihi: 25.10.2017).
} 
akademi $\% 16.8$, tıbbi hizmetler $\% 13.0$, sivil toplum örgütleri $\% 9.8$, yaşlı refah $1 \% 4.8$, engelli refah $1 \% 4.0$ ve son olarak da $\% 3.5$ ile belediye tercihi yapılmıştır. Işıkhan ve arkadaşlarının yaptığı bir araştırmaya göre sosyal hizmet öğrencileri akademiyi \%12 olarak ikici sırada ve sivil toplum örgütlerini ise \%2.3 ile tercih etmişlerdir (Işıkhan vd., 2016: 16). Belediyelerin sosyal hizmet alanında fazlaca rol oynamış olmalarına rağmen çalışma alanı olarak öğrenciler tarafından tercih edilmemesinin sebebi belediyelerin sosyal hizmet birimlerinde sosyal hizmet mezunu çalıştırmak yerine farklı bölümlerden eleman aldığı ya da öğrencilerin bu alanı tam olarak bilmediği düşünülebilir.

Grafik 3: Sosyal Hizmet bölümünü bilim ve meslek odaklı baktı̆̆ımda bilimin daha ağır bastığını düşünüyorum.

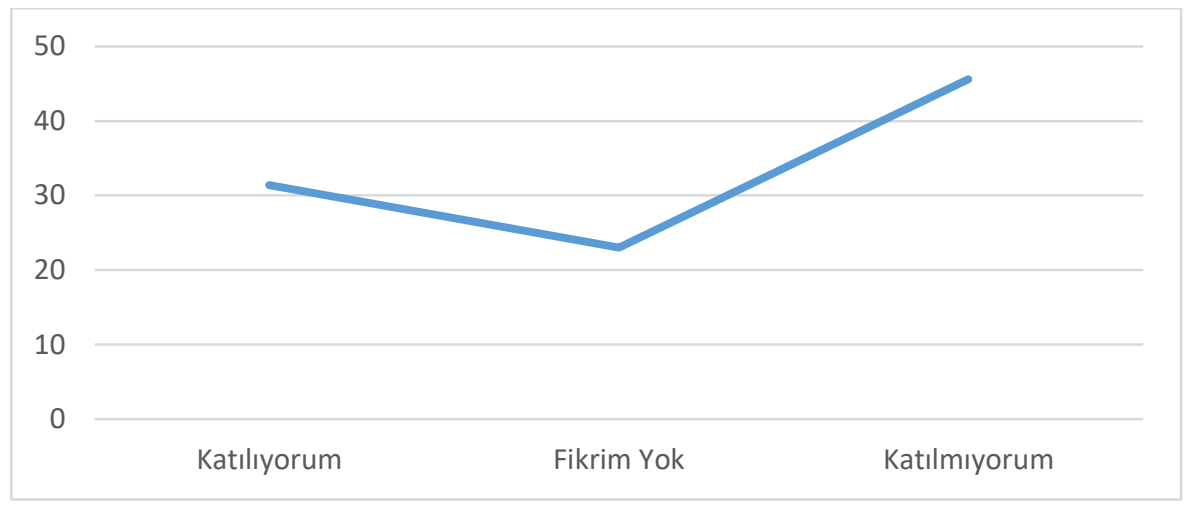

Sosyal hizmet hem mesleki bir uygulama hem de akademik bir disiplindir (Dixon, 2005: 254). Bu bağlamda sosyal hizmet bölümü hem teorik hem de uygulamalı eğitimi içeren bir müfredata sahiptir. Grafik 3'de öğrencilerin sosyal hizmet bölümünün niteliklerine yönelik görüşleri ele alınmıştır buna göre bölümün bilimsel yönünün ağır bastığını düşünen öğrencilerin oran $1 \% 31,4$ olurken, bu görüşe katılmayan öğrencilerin oranı ise \%45,6 ile daha ağır basmaktadır. Fikrim yok olarak cevaplayan öğrencilerin oran1 \%23 olduğu görülmüştür. 
Grafik 4: Bölümün daha çok uygulamaya yönelik olduğunu düşünüyorum.

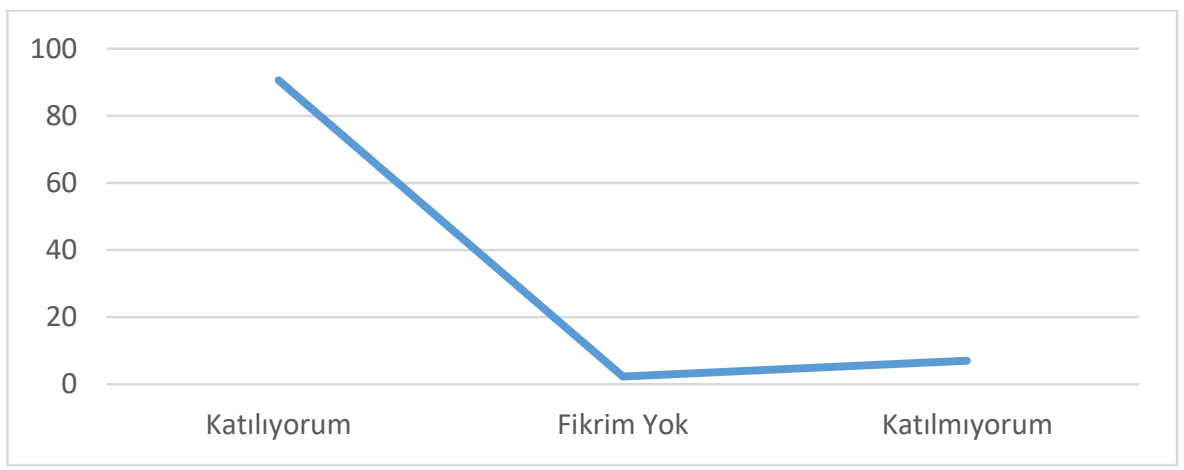

Grafik 4'de yer alan bir diğer soruda ise öğrencilere bölümün daha çok uygulamalı bir bölüm olduğuna katılıp katılmadıkları sorulmuştur. Öğrenciler \%90,6 gibi çok yüksek bir oranda uygulamalı bir bölüm olduğuna katıldıklarını belirtmişlerdir, bu görüşe katılmayan öğrencilerin oranı ise \%7,1'de kalmıştır. Kararsız öğrencilerin oranı ise \%2,3'de kalmıştır. Grafik 3 'deki veriler de dikkate alındığında öğrencilerin bölümü daha çok mesleki ve uygulama odaklı gördükleri anlaşılmaktadır.

Grafik 5: Bölümü isteyerek tercih ettim.

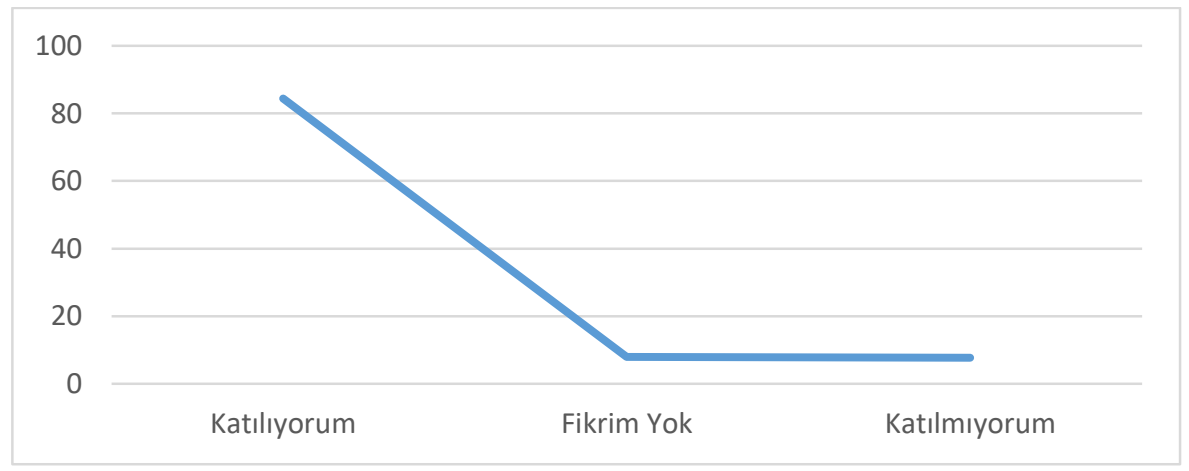

Grafik 5'de görüldüğü üzere öğrencilerin \%84,4'ü bölümü isteyerek tercih etmiştir. İsteyerek tercih etmeyenlerin oranı \% $\%, 7$ olurken bu konu da fikir beyan etmek istemeyenlerin oranın $\% 7,9$ olduğu görülmüştür. $\mathrm{Bu}$ 
bağlamda sosyal hizmet öğrencilerinin büyük çoğunluğu bölümü isteyerek tercih etmiştir.

Grafik 6: Türkiye’ de Sosyal Hizmet mesleğinin geleceğinden umutluyum.

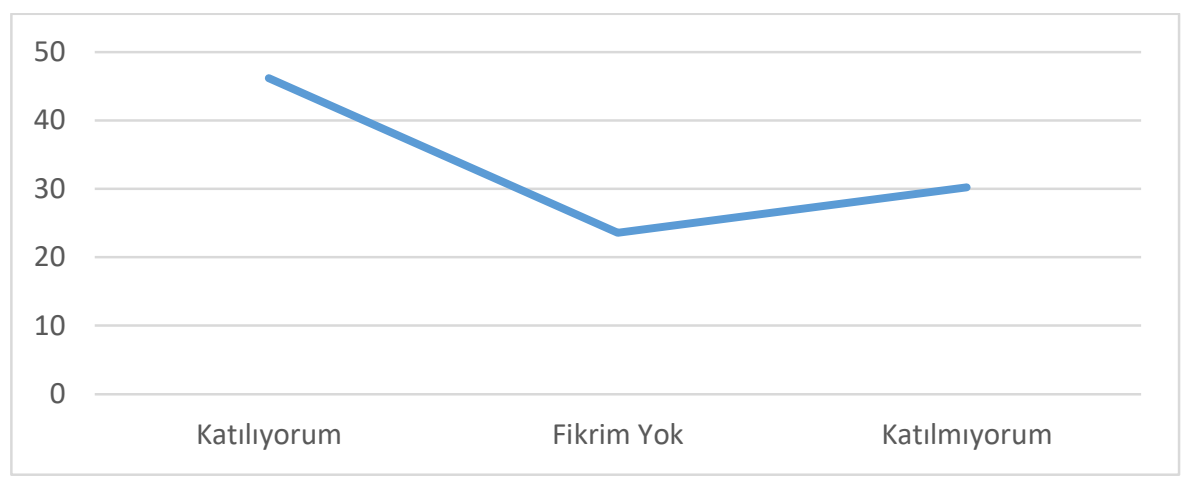

Grafik 6'da öğrencilere Türkiye' de Sosyal Hizmet mesleğinin geleceğinden umutlu olup olmadıklarına yönelik bir soru sorulmuştur. Buna göre katılımcıların \%46,2'si bölümün geleceğinden umutlu olduğunu belirtirken \%30,2'si ise umutlu olmadıklarını ifade etmişlerdir. Bölümü geleceği konusunda \%23,6 gibi azımsanamayacak bir oranda öğrenci ise kararsız kaldıkları görülmüştür.

Grafik 7: Açık öğretimin açılması iş bulmamı kötü etkilediğini düşünüyorum.

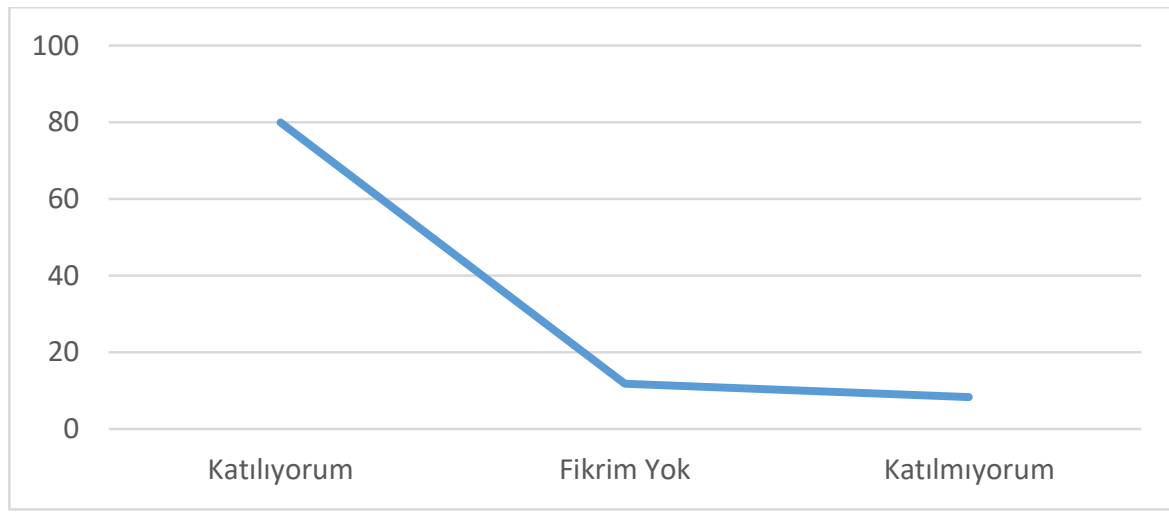

Son yıllarda birbiri ardına sosyal hizmet açık öğretim programları açılmaya başlanmıştır. Bu programların açılırken ihtiyaç tespitinin yapılıp 
yapılmadığı tam olarak bilinmemektedir. Bu gelişmenin sosyal hizmette örgün eğitim alan öğrencilerin iş bulma durumlularını olumsuz etkileyeceği düşünülmektedir. Araştırmamızda elde edilen sonuçlar da bu görüşü doğrulamaktadır. $\mathrm{Bu}$ bağlamda Grafik 6'da öğrencilere açı öğretim programlarının açılmasının iş bulmalarını olumsuz etkileyip etkilemeyeceği sorulmuştur. Buna göre öğrencilerin \% 79,9 'u gibi önemli bir bölümü olumsuz etkileri olacağ1 görüşüne katıldıklarını belirtmişlerdir. $\mathrm{Bu}$ görüşe katılımcıların \%8,3'ü katılmazken \%11,8'i fikir beyanında bulunmamışlardır.

Grafik 8: Bölümle ilgili istihdam olanaklarının yeterli olduğunu düşünüyorum.

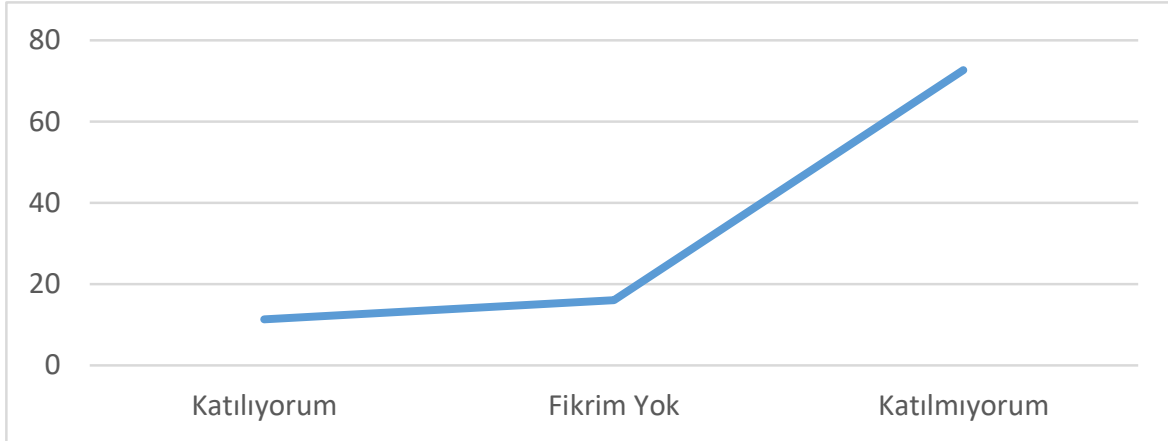

Sosyal hizmet mezunlarının istihdam noktasında yaşadıkları sorunlarda bir artış olduğu bilinmektedir. TUİK verilerine dayandırılarak yapılan bir araştırmada üniversite mezunları arasında en yüksek işsizlik oranının \%24 ile sosyal hizmet alanında yaşandığı tespit edilmiştir. ${ }^{2}$ Araştırmamızda elde edilen bulgulara göre bu gelişmelerin sosyal hizmet öğrencilerine yansıması olumsuz yönde olmuştur. Grafik 8'de öğrencilere istihdam olanaklarının yeterli olup olmadığına yönelik soru yöneltilmiş olup buna göre katılımcıların \%72,7'si yeterli olmadığını belirtmiştir. Yeterli olduğunu düşünülerin oranı $\% 11,3$ olurken karasız kalanların oranının ise \%16 olduğu görülmüştür.

\section{SONUÇ}

Türkiye'de sosyal hizmet bölüm sayısı ve kontenjanlarında yaşanan hızlı artış ve bunun yanı sıra birbiri ardına açılan açık öğretim programları bu

\footnotetext{
${ }^{2}$ http://www.milliyet.com.tr/iste-en-cok-istihdam-edilen-meslek--ekonomi2420212, (Erişim tarihi: 25.10.2017).
} 
bölümü okuyan öğrenciler üzerinde bir gelecek kaygısı oluşturmaya başlamıştır. Sosyal hizmet bölümü öğrencilerinin mevcut durumu ile gelecekte yaşayabilecekleri problemlere yönelik farkındalıklarının tespit edilmesi farklı çözümlerin geliştirilmesi için önem arz etmektedir. Sosyal hizmet genel olarak vurgulandığı gibi hem bir mesleki uygulama alanı hem de akademik bir disiplin olduğu kabul edilmektedir. Buna göre, bu çalışmada öğrencilerin hem teorik hem de uygulama çerçevesinde bölüme yönelik algıları ve beklentileri tespit edilmesi hedeflenmiştir.

Çalışmadan elde edilen bulgulara göre sosyal hizmet öğrencileri literatürü ağırlıklı olarak sosyal medya ve internet gibi dijital mecralarda takip ettikleri görülmüsştür. Bunun yanı sıra literatürün en az takip edildiği kaynak dergiler olduğu sonucuna ulaşılmıştır. Bu durum öğrencilerin alan ile ilgili akademik makalelere yeterince ilgi göstermediklerini ortaya koymuştur. Bir diğer bulguya göre, öğrencilerin mezuniyetten sonra ağırlıklı olarak çocuk refahı alanında çalışmayı istedikleri görülmüştür. En az çalışmak istedikleri alan olarak da belediyeleri ifade etmişlerdir. Sosyal hizmetin en önemli çalışma sahalarından biri olan yerel yönetimlere karşı ilgilerinin düşük olması, belediyeler ile sosyal hizmet bölümlerinin karşılıklı işbirliklerinin az olduğu ya da öğrencilerin bu alanı yeterince tanımamalarından kaynaklandığı şeklinde yorumlanabilir.

Çalışmadan genel olarak elde edilen en önemli sonuçlardan biri de sosyal hizmet bölümü öğrencilerinin mesleki gelecek kaygılarının yüksek olduğudur. $\mathrm{Bu}$ bağlamda bölüm sayısının ve öğrenci kontenjanlarının kontrolsüzce artması bu durumun en önemli nedenleri olarak karşımıza çıkmaktadır. Araştırma kapsamında öğrencilerden elde edilen verilere göre öğrencilerin çok büyük bir çoğunluğu istihdam olanaklarının da yeterli olduğunu düşünmemektedir.

Sonuç olarak sosyal hizmet alanında yeni istihdam alanları oluşturulmadan mevcut durum devam ederse ilerleyen yıllarda sosyal hizmetin istihdam olanaklarının daha da zorlaşacağı ve bu durumunda öğrencilerin gelecek kaygısını daha da artıracağı düşünülmektedir. Tüm bu gelişmeler sonucunda sosyal hizmet mesleğine yönelik iyi bir insan kaynakları 
planlamas1 ve istihdam projeksiyonu belirlenmezse sosyal hizmet bölümünün tercih edilebilir bölüm olmaktan uzaklaşması kaçınılmaz olacaktır.

\section{KAYNAKLAR}

Acar, H. ve Çamur Duyan, G. (2003). Dünyada sosyal hizmet mesleğinin ortaya çıkışı ve gelişimi. Toplum ve Sosyal Hizmet, 14(1), 1-19.

Alptekin, K., Topuz, S., ve Zengin, O. (2014). Türkiye'de çocuğun refahı ve korunması: kapsayıcı bir yaklaşım arayışı. Türkiye'de sosyal hizmet eğitiminde mevcut durum: tespitler, analizler ve öneriler. Sosyal Hizmet Seтроzуити. 353-366. Kocaeli: Kocali Üniversitesi.

Danış, M. Z. (2007). Sosyal Hizmet Mesleği ve Disiplininde Sosyal Politikanın Yeri ve Önemi. Toplum ve Sosyal Hizmet, 18(2), 51-64.

Dixon, J. (2005). Foster carers: why they stay and why they leave (Book Reviews). Child and Family Social Work, 10, 249-254.

Freund, A. (2006). Work and work attitudes on social workers: do they predict organizational reputation? Business and Society Review, 111(1), 67-87.

Gökçearslan Çifci, E. ve Gönen, E. (2011). Sosyal hizmet uygulamalarında etik karar verme süreci. Toplum ve Sosyal Hizmet Dergisi, 22(2), 149160.

Hovardaoğlu, S. (2000). Davranış bilimleri için araştırma teknikleri. Ankara: VE-GA Yayınları.

Iş1khan, V., Erbay, E., Akçay, S. ve Ege, A. (2016). Sosyal hizmet bölümü öğrencilerinin mezuniyet sonrası gelecek planları: Ankara, Başkent ve Hacettepe üniversitesi örnekleri. Toplum ve Sosyal Hizmet Dergisi, 27(1), 7-24.

Iş1khan, V., Erbay, E., Akçay, S., ve Ege, A. (2016). Sosyal hizmet bölümü öğrencilerinin mezuniyet sonrası gelecek planları: Ankara, Başkent ve Hacettepe üniversitesi örneği. Toplum ve Sosyal Hizmet, 27(1), 7-24.

Karasar, N. (1999). Bilimsel araştırma yöntemi. Ankara: Nobel Yayın Dăğtım.

Olin, J. (2013). The public and the profession's perception of social work. Columbia Social Work Review, 4, 92-102.

Öztürk, A. B. (2009). Sosyal hizmet etiğinde farklı yaklaşımlar. Toplum ve Sosyal Hizmet, 20(1), 105-116.

Pierson, J. (2012). Understanding Social Work: History and Contex. New York: Mc Graw Hill Open University Press.

Pincus, A., ve Minahan, A. (1973). Social Work Practice: Model and Method. Itasca, IL: F.E. Peacock.

Sheafor, B. W. ve Horejsi, C. R. (2002). Techniques and guidelines for social work practice, 6. Bask1, AB Publication: Boston. 
Whitaker, T. (2008). Who wants to be a social worker? Career influences and timing. NASW Membership Workforce Study. Washington, DC: NASW.

Wilson, G. Ve McCrystal, P. (2007). Motivations and career aspirations of msw student in Nothern Ireland. Social Work Education, 26(1), 35-52.

Yiğit, T. (2017). Türkiye'de Sosyal Hizmet Eğitim/Öğretiminde. Kalite Güvence Sistemi ve Akreditasyon. Standartlarına İlişkin Bir Model Çerçeve Önerisi. Toplum ve Sosyal Hizmet, 28(1), 151-168. 